\title{
Does Working Memory Training Promote Changes in Fluid Intelligence?
}

\author{
Marcela Mansur-Alves ${ }^{1 *}$ \\ Laboratório de Estudos do Comportamento, Cognição e Aprendizagem (LECCA), \\ Departamento de Psicologia, Universidade Federal de Minas Gerais, \\ Belo Horizonte, $M G$, Brazil \\ Renata Saldanha-Silva \\ Faculdade Ciências Médicas de Minas Gerais, Belo Horizonte, MG, Brazil
}

\begin{abstract}
Intelligence is a main predictor for a variety of social, academic, and economical outcomes. Therefore, researchers have been increasingly dedicated to pursuing ways to improve intelligence. In the recent years, a great interest in working memory training programs has risen as a form to achieve changes in intelligence. However, the efficacy of these programs is still surrounded by controversies. The current review aims to perform a critical analysis of the literature, reassessing the effects of working memory training that leads to improvements in fluid intelligence. After data collection and a detailed literature review, the effects of working memory training leading to intelligence gain from 45 studies were assessed. A great variety in methodology was observed within the studies, which used mainly non-clinical samples, with some material incentive and an $n<30$. Raven was the predominant measure of efficacy for training in fluid intelligence, and the improvements in intelligence were significant for groups of children of similar age range and for longer training periods. The positive effects observed are still insufficient to indicate a transfer to fluid intelligence, suggesting that a more cautious approach of the current similar interventions may be necessary.
\end{abstract}

Keywords: Intelligence, cognitive training, working memory, far transfer.

\section{Treinar Memória de Trabalho Promove Mudanças em Inteligência Fluida?}

\section{Resumo}

A inteligência é um dos preditores mais robustos de uma variedade de resultados nos âmbitos social, acadêmico e econômico, por isso pesquisadores cada vez mais dedicam esforços para promover melhorias na inteligência. Nos últimos anos emergiu interesse em programas de treinamento em memória de trabalho como forma de promover mudanças na inteligência. Tais programas estão cercados de controvérsias. A presente pesquisa objetiva realizar uma revisão crítica de literatura, analisando os efeitos de transferência do treinamento em memória de trabalho para a inteligência fluida. Após levantamento e análise detalhada da literatura, foram reanalisados os efeitos de treino em memória de trabalho para

Mailing address: Universidade Federal de Minas Gerais, Departamento de Psicologia, Faculdade de Filosofia e Ciências Humanas, Avenida Antônio Carlos, 6627, Campus Pampulha, Belo Horizonte, MG, Brazil 31270901. E-mail: marcelamansuralves@yahoo.com.br ou marmansura@gmail.com

Acknowledgments: The authors thank the student Vinícius Fernandes Diniz, from the undergraduate psychology course at UFMG, for his contribution to the review of the literature review carried out for this article. 
ganhos em inteligência de 45 estudos. Como resultado, observou-se grande variabilidade metodológica entre os estudos, cuja maior parte usou amostras não clínicas, com algum incentivo material e $n<30$. $\mathrm{O}$ Raven predominou como medida de eficácia dos treinamentos em inteligência fluida, e os aumentos na mesma foram significativos para os grupos etários de crianças e treinamentos mais longos. Os efeitos positivos encontrados são insuficientes para indicar uma transferência real para inteligência fluida, o que sugere a necessidade de maior cautela no uso atual de intervenções semelhantes.

Palavras-chave: Inteligência, treino cognitivo, memória de trabalho, transferência.

\section{¿Entrenar Memoria de Trabajo Promueve Cambios en la Inteligencia Fluida?}

\section{Resumen}

La inteligencia predice resultados diversos en la vida social, académico y económico, por lo que los investigadores cada vez más esfuerzos dedican a promover cambios positivos en la inteligencia. En los últimos años surgió el interés por los programas de entrenamiento de memoria de trabajo con el fin de promover cambios en la inteligencia. Dichos programas están rodeados de controversia. Esta investigación tiene como objetivo realizar una revisión crítica de la literatura sobre los efectos del entrenamiento en la memoria de trabajo para la inteligencia fluida. Después de la inspección y el análisis detallado de la literatura, fueron reanalizados los efectos de 45 estudios. Como resultado, existe una gran variabilidad metodológica entre los estudios, la mayoría de los cuales utilizan muestras no clínicas, con un poco de estímulo material y $n<30$. El Raven era la medida predominante de la eficacia. Los aumentos fueron significativos para los grupos de los niños y entrenamientos de mayor duración. Los efectos positivos encontrados son insuficientes para indicar una transferencia real para la inteligencia fluida, lo que sugiere la necesidad de una mayor precaución en el uso actual de intervenciones similares.

Palabras clave: Inteligencia, entrenamiento cognitivo, memoria de trabajo, transferencia.

The cognitive training literature has been inundated with recent interest, mostly due to constant and consistent affirmations on working memory (WM) plasticity (Astle, Barnes, Baker, Colclough, \& Woolrich, 2015). The working memory - ability to store and manipulate information for short periods of time - is an important predictor of school performance, and is also involved with reasoning, solving mathematical problems, maintaining focused attention, making decisions, reading and abstract thinking (Baddeley, 2003; Ilkowska \& Engle, 2010). The scientific community interest is even greater when considering the results from some studies showing that the gains obtained in WM training can be transferred to abilities, or cognitive processes not directly trained, in these programs (a phenomenon known as far transfer), for example, for attention, executive functions or fluid intelligence (Gf; Buschkuehl \& Jaeggi,
2010; Jaeggi, Buschkuehl, Jonides, \& Perrig, 2008; Klingberg, 2010; Klingberg et al., 2005; Klingberg, Forssberg, \& Westerberg, 2002). The possible gains observed in fluid intelligence tests are of interest for this review. From the psychometric point of view, fluid intelligence is the ability to create analogies, reason and solve new problems, extract meaning and to adapt to new situations (Jensen, 1998). This is usually measured through figurative, inductive and analogical reasoning tests, classification and matrices tests, such as Raven's Progressive Matrices, which constitutes one of the most commonly used instrument to assess Gf. A significant number of studies indicate that, among the most relevant intellectual factors, $\mathrm{G} f$ seems to be the closest to the theoretical conception of the $g$-factor, as proposed by Spearman (Jensen, 1998). In fact, some researchers claim that fluid intelligence and general intelligence are almost 
equivalent constructs (Ackerman, Beier, \& Boyle, 2005), a presupposition that has been partially questioned by recent studies (Gignac, 2015). In addition, $\mathrm{G} f$ predicts in a consistent and robust way, distinct aspects of individual functioning, as school performance and attendance, occupational performance, income, disruptive behavior, neurodegenerative diseases, physical health, among others (Neisser et al., 1996; Nisbett et al., 2012). A consistent pattern of psychometric, clinical and neuroanatomical similarities provides the basis for the premise that the WM training could increase performance in fluid intelligence tests. Many studies have indicated a moderated or high association (above 0.50 ) between WM and fluid intelligence tasks, indicating that both could share a common underlying structure (Kyllonen \& Christal, 1990; Oberauer, Suß, Schulze, Wilhelm, \& Wittmann, 2000; Orzechowski, 2010; Stauffer, Ree, \& Caretta, 1996). There are also similarities from a neuroanatomical and clinical point of view. Neuroimaging studies using clinical and nonclinical sample have indicated that both working memory tasks and fluid intelligence tests recruit circuits located in the frontal and parietal lobes, and this recruitment seems to be moderated by the difficulty and familiarity with the task (Baddeley, 2003; Colom, Jung, \& Haier, 2007; Deary, Penke, \& Johnson, 2010; Jung \& Haier, 2007; Kane \& Engle, 2002; Li et al., 2009; Miller \& Cohen, 2001; Woolgar et al., 2010). If these conclusions are correct, the social, educational and professional implications are considerable, since there is extensive literature indicating that intelligence is the best individual predictor for a variety of social phenomena (Strenze, 2007). Precisely for this reason, cognitive training programs currently drive a billion-dollar industry (Hayes, Petrov, \& Sederberg, 2015).

The debate over the malleability of intelligence is outdated, originating back in the 19th century and to the studies of Francis Galton, which pointed to a high influence of genetics on individual differences in intelligence ( $\mathrm{Au}$ et al., 2015; Burt, 1962; Rushton, 1990). Modern thinkers are also skeptical about the possibility of changes in intelligence, emphasizing its elevated heritability and stability throughout the life cycle (Au et al., 2015). This outdated philosophy that was accepted 30 years ago, is based on the results of classical intervention programs, for which the effect is null or in small magnitude, often disappearing almost completely over time (Hernstein \& Murray, 1994; Jensen, 1981).

However, recent evidences suggest that intelligence can be malleable. A solid body of knowledge accumulated over generational gains in intelligence - phenomenon known as Flynn Effect - seems to point out several environmental factors (for example: nutrition, industrialization, schooling, technological advances, among others) could have beneficial effects on intelligence, even in the long term (Flynn, 1987, 2006; Nisbett et al., 2012). In this context, results from intervention programs emerged also showing that working memory could be the vehicle for the changes in intelligence (Alloway, Bibile, \& Lau, 2013; Borella, Carretti, Zanoni, Zavagnin, \& De Beni, 2013; Borella et al., 2014; Jaeggi et al., 2008; Jaeggi, Buschkuehl, Jonides, \& Shah, 2011; Jaušovec \& Jaušovec, 2012; Klingberg et al., 2005; Klingberg et al., 2002; Rudebeck, Bor, Ormond, O'Reilly, \& Lee, 2012; Schmiedek, Lövdén, \& Lindenberger, 2010; Stephenson \& Halpern, 2013; Zinke et al., 2014). The basic assumption of these programs consists in request the WM system of the participants to work at its maximal capacity to stimulate an increase in their functioning. When this occurs, improvements could then be transferred to other similar tasks and cognitive systems that depend somehow on the integrity of the WM (Au et al., 2015; Jaeggi et al., 2008; von Bastian \& Eschen, 2016). This possibility, which at first sight was so attractive to researchers, led to the development of intervention programs in WM designated for different age groups, displaying typical development or not.

Although there has been some initial success, after more than 10 years of research on the transference of WM training gains to intelligence, the results still remain contradictory (Melby-Lervåg \& Hulme, 2013; Redick, Shipstead, Wiemers, Melby-Lervåg, \& Hulme, 2015; Shipstead, Redick, \& Engle, 2012). Some authors report 
positive results, pointing to increased fluid intelligence (Borella, Carretti, Riboldi, \& De Beni, 2010; Borella et al., 2014; Jaeggi et al., 2008; Jaeggi et al., 2011; Rudebeck e al., 2012; Zinke et al., 2014) while others do not report such evidence and remain unconvinced of the extent to which intellectual plasticity can be maintained for long periods of time after completed training, especially after such brief and punctual interventions (Chooi \& Thompson, 2012; Harrison et al., 2013; Melby-Lervåg \& Hulme, 2013, 2015; Pugin et al., 2015; Shipstead et al., 2012; Thompson et al., 2013). The comparison between the findings from different research groups complicates this scenario, mainly because the methodology used in these studies is extremely diverse, varying from the task used for WM training to the total time and duration of the intervention (Au et al., 2015; Buschkuehl \& Jaeggi, 2010; Melby-Lervåg \& Hulme, 2013, 2015; Redick et al., 2015). Without a detailed analysis of the published results on this subject, conclusions regarding the benefits of WM training programs for intelligence is premature.

Systematic reviews are important tools providing detailed analysis of published studies and in enabling clarification of training program effects. The studies systematization allows for a reanalysis of obtained data and controlling factor variation. Previous systematic reviews published on this subject generally seek to analyze the effects of training on WM specific tasks (n-back, for example). Nevertheless, those systematic reviews have investigated the effects of training programs for mixed intelligence measures or even measures that operationalize other factors of second order - not specifically fluid intelligence (see details Au et al., 2015; Buschkuehl \& Jaeggi, 2010; Melby-Lervåg \& Hulme, 2013; Shipstead et al., 2012). Additionally, the referred studies do not include articles written in Portuguese language, which results in excluding studies carried out with Brazilian samples.

Therefore, the aim of this study was to verify the extent of the training effects on working memory to fluid intelligence, latent construct not directly trained by tasks used in the interventions (far transfer effects). The assumption for far transfer effect to occur is the existence of underlying mechanisms shared by two or more cognitive abilities. This is the desirable type of transference and that which produces significant cognitive changes (Barnet \& Ceci, 2002). In addition, because of the large methodological variation among published studies, our aim was to verify how these differences between the studies may impact the results.

\section{Method}

This review was carried out following the general guidelines of the PRISMA (Preferred Reporting Items for Systematic Reviews and Meta-Analyses) ${ }^{2}$ statement, which includes guidelines to perform and report systematic reviews and meta-analysis. However, some inclusion criteria used in this review were based on Melby-Lervåg and Hulme (2013) guidelines for working memory intervention studies.

The articles were surveyed from August to December 2015. To be included, studies had to use a working memory intervention, and included standardized fluid intelligence $(\mathrm{G} f)$ tests as a measure to evaluate the efficacy of the intervention. Such tests are mostly composed of non-verbal stimuli, only slightly dependent on previously acquired knowledge and influence of cultural aspects. The mental operations required for fluid intelligence tasks include the formation and recognition of concepts, the identification of complex relationships, inductive reasoning, the comprehension/understanding of implications and the making of inferences (Jensen, 1998; McGrew, 2009). Since the analysis indicated the existence of great diversity of $\mathrm{G} f$ measures used to evaluate the efficacy of intervention, this review only included analysis of the average and standard deviations of those intellectual measures cited in more than $10 \%$ of the total sample of all selected studies. This criterion aimed to ensure that the intelligence measure used to evaluate the efficacy was recognized as adequate (through the quantity of citation) to measure the construct.

www.prisma-statement.org 
In this current analysis, the $\mathrm{G} f$ measure analyzed were: Raven's Progressive Matrices (Raven), Bochumer Matrizen-Test (BOMAT), and Culture Fair Intelligence Test (CFIT). The three instruments are measures of non-verbal intelligence, contain multiple choices and are independent of culture. The Raven's Progressive Matrices evaluate inductive reasoning, using abstract figures, and some of its items require the use of visual-spatial skills with increasing levels of difficulty. In each item, the participant is required to select, between 6 to 8 alternatives, the missing segment to complete a larger picture, presented at the top of the page. The instrument has three versions - Colored, Standard, and Advanced scale that vary in number of items and complexity per age group and intellectual level (Klingberg et al., 2002; Wang, Zhou, \& Shah, 2014). In a similar way, BOMAT is a test of matrices composed of abstract figures organized according to a logical pattern, with one of its elements left blank, which demand inductive reasoning. The difficulty levels are also increasing. The difference is that, while Raven matrices are $3 \times 3$ elements, BOMAT are of $5 \times 3$, and the latter is considered more difficult than the first (von Bastian, Langer, Jäncke, \& Oberauer, 2013). CFIT is composed of four different nonverbal subtests, which include matrices, classifications, conditions and series, that involve different cognitive operations, such as recognition and formation of concepts, inductive reasoning and problem solving. It is composed of three versions indicated for different age groups and intellectual levels (Borella et al., 2013). The analyses were performed separately for each one of the three $\mathrm{G} f$ measures. A detailed description of the literature search method and inclusion criteria can be seen in Figure 1.

For inclusion in this review, the study should have an experimental design with a control and an experimental group, random allocation of participants in each group, and use at least one $\mathrm{G} f$ instrument in the pre-test and in the post-test. When a study included more than one control group (for example, one active control group and another passive control group) a decision was made to analyze the means and standard deviation only of the active control group. This is because it is known that results from studies involving active control group are more reliable since, in cases of intervention studies, they reduce the probability that the improvements observed in the experimental group are due to placebo (Redick et al., 2015).

Studies that did not present mean and standard deviation information for $\mathrm{G} f$ measurements in the pre-test and post-test were excluded from the analyses. The size/magnitude of the effect was calculated using the Hedges $g$, which represents the Cohen's $d$ corrected for small size samples (Hedges \& Olkin, 1985). The effect size calculation was performed to estimate the difference between the experimental group, which received training, and the control group. Positive effect sizes indicate greater gains for the experimental group. For weighting of the results according to the quality of the studies, weight was calculated, which consist of the inverse of the studies variance. Therefore, the Hedges $g$ indexes were multiplied by the weights of the studies, to ensure that those of higher quality - that is, with lower variance and larger sample size - had greater representation in the analysis (Neyeloff, Fuchs, \& Moreira, 2012).

To analyze the level of heterogeneity between the studies, Cochrane's Q and $\mathrm{I}^{2}$ were calculated. Both indexes test the null hypothesis that all studies included in this review are measuring a same effect size (and that the variations, in this case, are due to sampling errors). Here, we decided to use these two measures to ensure a more rigorous analysis, since Cochrane's Q, although it is the most widely used measure, may be inaccurate for analysis with a small number of studies, in which cases it is suggested to use $\mathrm{I}^{2}$ (Higgins, Thompson, Deeks, \& Altman, 2003). For interpretation of Cochrane's Q, significant results indicate high heterogeneity. For analysis of $\mathrm{I}^{2}$ values above 25 and above 75 are indicative of moderate and high heterogeneity, respectively (Higgins et al., 2003). The results of the heterogeneity tests were used to define the type of effect synthesis analysis to be used: fixed effect or random effect. Fixed effect presupposes the existence of homogeneity between the studies while random effect presupposes between-study 


\section{SEARCH \\ Electronic Databases}

Scopus, PsycNet, Scielo and Google Scholar

Keywords

"Working Memory Training" e "Intelligence"; "Working Memory Training" e "Reasoning", and their variations in Portuguese.

\section{PAPERS SCREENING \\ Number of papers collected (after duplicates removed) \\ 400 articles}

\section{INCLUSION CRITERIA}

- Full-text articles, written in Portuguese, English or Spanish

- The studies involved working memory training exclusively

- The pre- and post-test measures included at least one fluid intelligence test (Gf)

- Participants from control and experimental groups were randomly chosen

- The information available in the article or in supplementary material must enable to compute size effect in intelligence

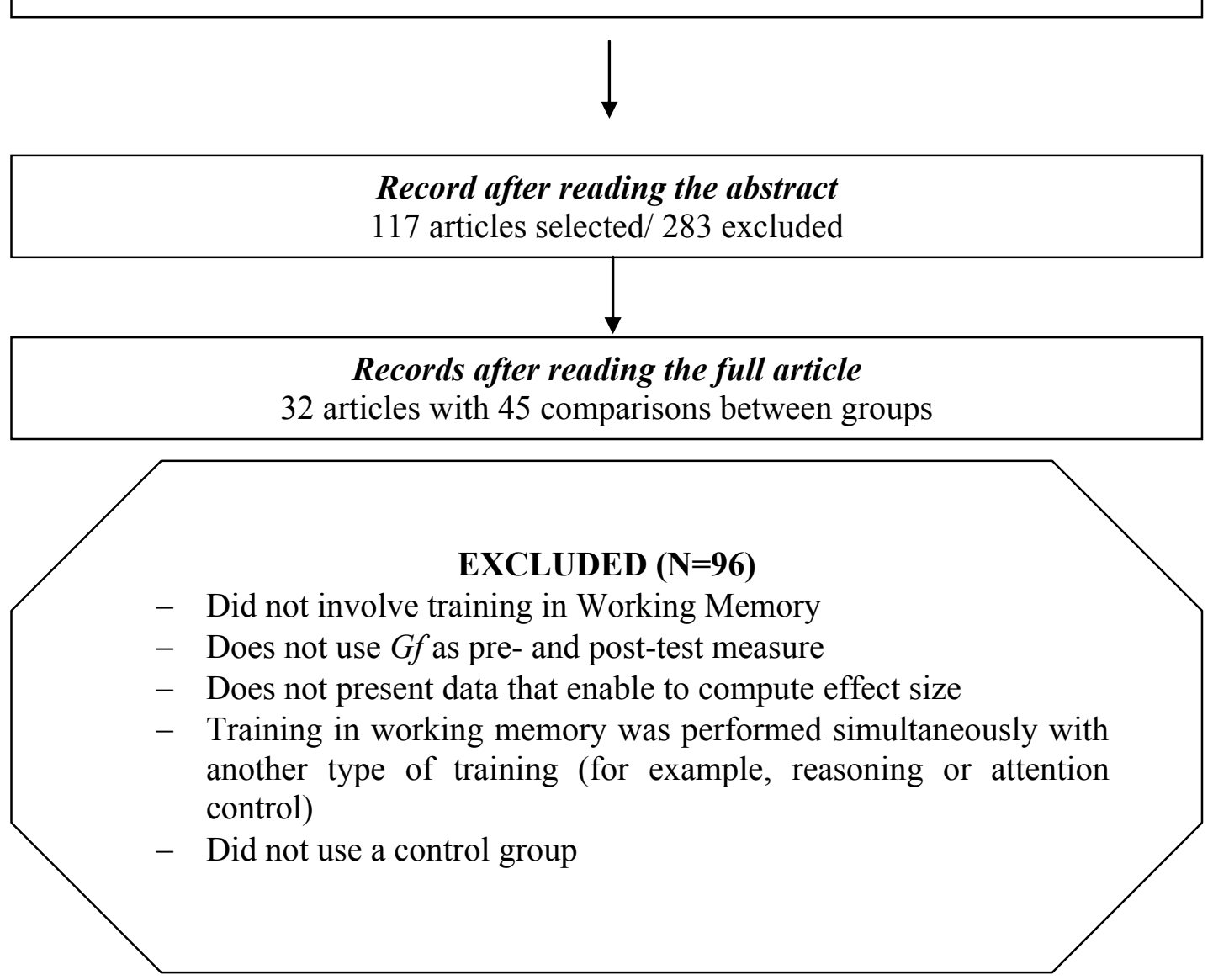

Figure 1. Description of the literature search method and inclusion criteria. 
variations, in addition to sampling errors (Neyeloff et al., 2012).

For a graphical analysis of the $\mathrm{G} f$ results, Forest Plots were created, in which the effect size was presented in each study for comparison, in addition to the total mean effect (Li \& Shotton, 2013). The publication bias was analyzed from a funnel plot only for Raven, since this procedure is not indicated to samples with less than 10 studies (Pereira \& Galvão, 2014). Funnel plots are scatter plots, presenting the effect size on the abscissa axis and precision (inverse of variance) on the ordinate axis. Less accurate studies would be distributed symmetrically in the wide part of the funnel, while the most accurate studies would be in the narrowest part. Settings that were different than expected (for example, a higher number of studies with positive results) would indicate a publication bias. This indicates that a certain portion of the studies - often those with negative or non-significant result - were not found. It is possible that an editorial or author decision to not publish articles with negative or non-significant results limits the availability of many studies from the current literature (Pereira \& Galvão, 2014).

The following moderator variables were used to examine the variability in effect sizes between the studies:

1. Age. The participants were divided into age groups as follows: children/adolescents (18 years or younger), adults (19 59 years) and the elderly (over 60 year);

2. Intensity of training. Studies with a total duration of less than 8 hours were considered of low intensity and studies with total duration above 8 hours were considered of high intensity. The classification was according to the Melby-Lervåg and Hulme (2013) criteria.

3 . Type of control group. The studies were divided in two groups, according to the type of intervention performed with the control group, namely: (a) passive control group (no-contact) - received no intervention; and (b) active control group - The task performed by the control group was of a different nature than the task performed by the experimental group.

4. Type of task used for training. The WM tasks used were coded according to their content in: visuospatial (which did not use alphanumeric symbols, carrying the visuospatial sketchpad), verbal (with main content carrying the phonological loop) and both (when the intervention program was aimed to work in both systems, simultaneously).

5. Material incentive. The studies were coded into two groups: those whose participants received incentives to join (for example, money or gifts) and those whose participation did not involve receiving any type of material bonus.

The difference between types of practice (distributed $\mathrm{x}$ concentrated) could not be accounted/computed, since less than three studies used distributed practice (less than 3 sessions per week). The same occurred for comparisons between the studies with clinical and non-clinical samples, since less than three studies were performed with clinical samples. To identify the differences between the general mean effects in each moderating variable, $Z$ tests were performed for comparing subgroups (Borenstein, Hedges, Higgins, \& Rothstein, 2009).

\section{Results}

Detailed information regarding all the studies included in this review is presented in Table A1 (Appendix A). Most of the studies were performed with small sample size $(n<30)$, non-clinical, and with the use of material incentives for participants. A large part of the studies (74\%) used some version of Raven Progressive Matrices (Coloured, Standard or Advanced), which indicates some agreement in the chosen measure to evaluate the effectiveness of WM training. The heterogeneity tests revealed moderate to high variability among the studies, even after exclusion of extreme values (more than 2 standard-deviation from the sample mean). Therefore, general mean effect size analyses were performed for random effects (Neyeloff et al., 2012). The results for analysis of publication 
A
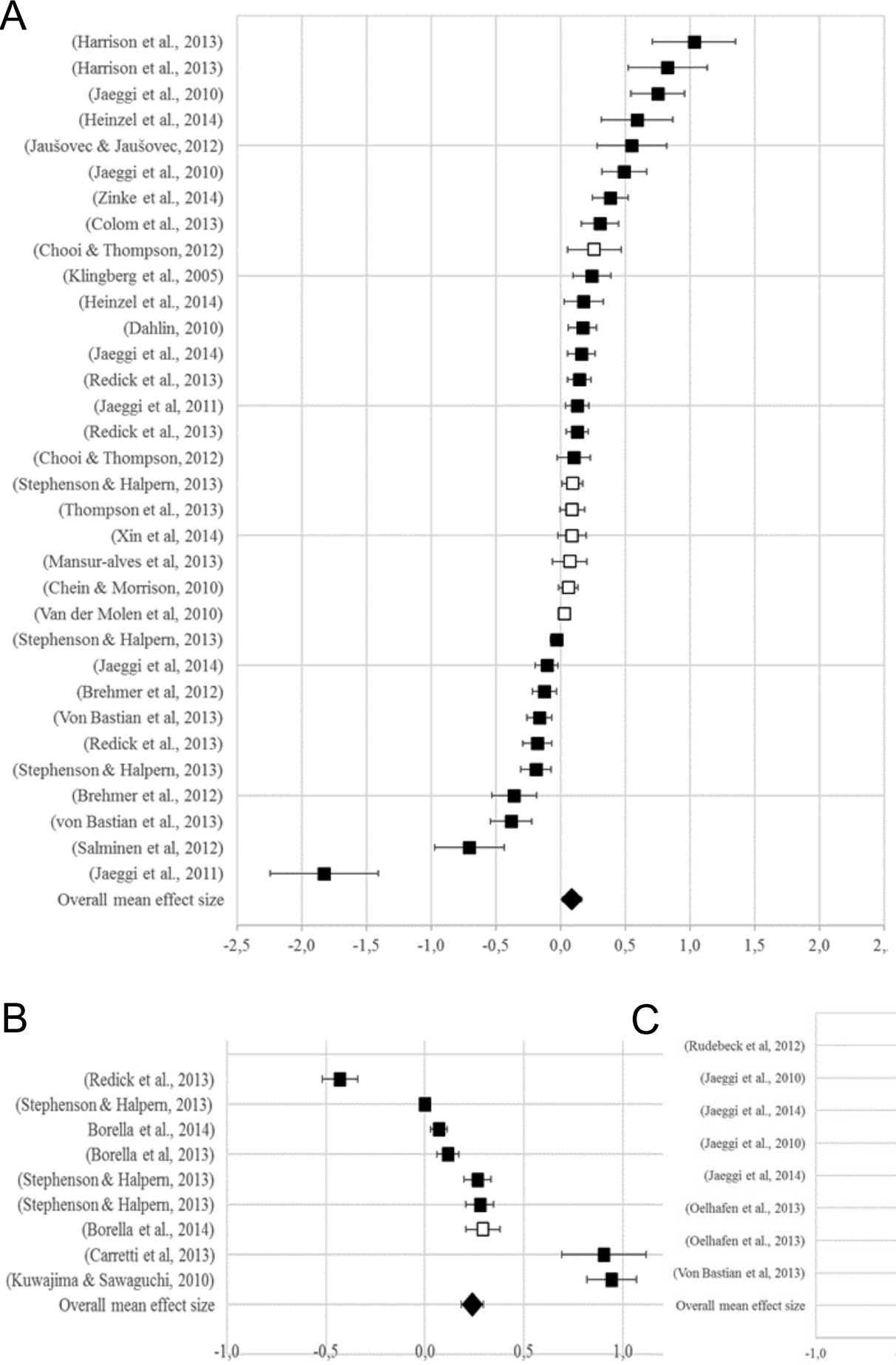

C

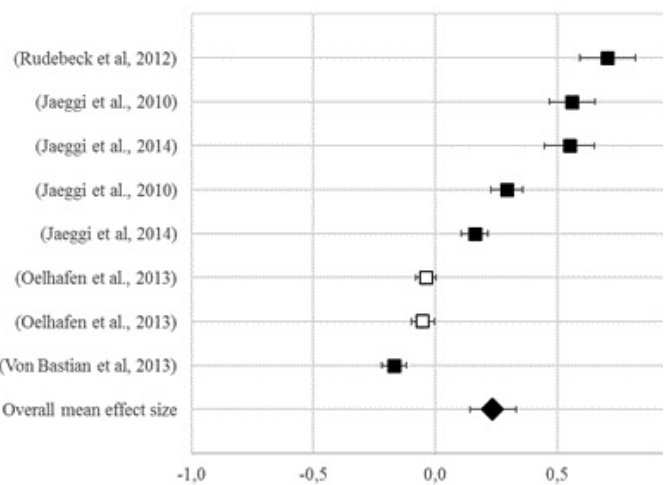

Figure 2. Forest plot for working memory training effects on the Raven (A) CFIT (B) and BOMAT (C), for each specific study evaluated in this review. Confidence intervals are represented by horizontal lines. Unfilled markers indicate non-significant effect.

bias indicated that there was no bias for the studies using Raven. This result is shown in Figure $1 \mathrm{~B}$ of the Appendix B.

Figure 2A shows the Forest Plot with 33 results found in the Raven ( $n$ of the training group $=800 ;$ mean $=24.24 ; S D=8.62 ; n$ of the control group=827; mean=25.06; $S D=10.57$ ). The overall mean effect size was $0.09(0.02-0.16$, for 95\% Confidence Interval, with $p<.001)$. The group heterogeneity was high, with $\mathrm{Q}=121.11$ $(p<.001)$ and $\mathrm{I}^{2}=73.58 \%$, even after exclusion of the cases with extreme values. 
Table 1

Analysis of the Homogeneity of the Studies Considering the Moderators for the Raven

\begin{tabular}{|c|c|c|c|c|}
\hline Moderators & $N$ & $\mathrm{G}$ & $\mathrm{Q}$ & $\mathrm{I}^{2}$ \\
\hline \multicolumn{5}{|l|}{ Age group } \\
\hline Children/adolescents & 05 & $0.12^{* *}$ & \multirow{3}{*}{$164.16^{* *}$} & -23.99 \\
\hline Adults & 22 & $0.15^{* *}$ & & 64.14 \\
\hline Elderly & 06 & -0.27 & & 65.66 \\
\hline \multicolumn{5}{|l|}{ Intensity of training } \\
\hline Up to 8 hours & 10 & -0.03 & \multirow{2}{*}{$130.85^{* *}$} & 38.11 \\
\hline Above 8 hours & 23 & $0.12^{*}$ & & -74.58 \\
\hline \multicolumn{5}{|l|}{ Type of CG } \\
\hline Passive & 09 & 0.26 & \multirow{2}{*}{$189.97^{* *}$} & 14.54 \\
\hline Active & 24 & 0.03 & & 77.23 \\
\hline \multicolumn{5}{|l|}{ Type of training } \\
\hline Visuospatial WM & 05 & $0.12^{*}$ & \multirow{3}{*}{$15.59^{* *}$} & 61.87 \\
\hline Verbal WM & 06 & 0.13 & & 36.40 \\
\hline Mixed WM & 22 & 0.06 & & -124.34 \\
\hline \multicolumn{5}{|l|}{ Material Incentive } \\
\hline Present & 23 & 0.07 & \multirow{2}{*}{3.76} & -40.92 \\
\hline Absent & 04 & 0.12 & & -3.52 \\
\hline
\end{tabular}

Note. CG, control group; WM, Working memory.

${ }^{*} p<.05 ;{ }^{* *} p<.01$.

The Forest Plot with the CFIT results is shown in Figure 2B (training group $n=194$; mean $=21.56 ; S D=5.79$; control group $n=221$; mean $=24.56 ; S D=8.59)$. The overall mean effect size was $0.24(0.14-0.34$, for $95 \%$ Confidence Interval, $p<.05)$. The heterogeneity of the group was moderate, with $\mathrm{Q}=15.81(p<.05)$ and $\mathrm{I}^{2}=49.39 \%$, even after exclusion of cases with extreme values.

The effects on BOMAT are also presented in Figure 2C (training group $n=186$; mean $=$ 23.25; $S D=6.63$; control group $n=216$; mean $=27.00 ; S D=13.42)$. The overall mean effect $/$ effect mean size was significant and of small magnitude $(g=0.24 ; p<.05)$. The degree of heterogeneity between the studies was moderate $\left(\mathrm{Q}=10.27 ; p>.05 / \mathrm{I}^{2}=31.87\right)$. In general, the size effect between the post-test and the pre-test, between experimental group (EG) and control group (CG), found in Raven were smaller than those found from CFIT and BOMAT. The number of studies using Raven is larger and no publication biases were observed. Furthermore, Raven is considered one of the most consistent and reliable measures, and has the highest factorial load in $\mathrm{G} f$ (for details see, Ackerman et al., 2005; Au et al., 2015; Carpenter, Just, \& Shell, 1990; Gray \& Thompson, 2004; Jensen, 1998). Therefore, it is considered that the results obtained for the Raven could represent the real effect of WM training and its far transfer to $\mathrm{G} f$. This issue will be discussed further in the discussion section.

The effects analyzed by the moderating variable are shown in Table 1, whenever the sample size permits (at least 3 studies per subgroup). Analysis of the Raven through moderating variable indicates significant and positive 
effects (i.e., in favor of the intervention group), however their magnitude was small. Increases in $\mathrm{G} f$ were significant for children/adolescents and adults, longer duration training programs, and training with visuospatial WM tasks. Other results did not reach statistical significance. Comparison analysis between the subgroups ( $Z$ test) showed significant differences only for children/ adolescents compared to adults $(Z=130.37 ; p$ $<.001)$.

The long-term effects of the interventions were also investigated. Follow-up data were found in 8 of the studies that used Raven and in 3 of the studies that used CFIT. For the Raven test, the interval from the immediate post-test to the follow-up ranged from 90 and 270 days (mean $=170$ days; $S D=96.12$ ). For the three studies that used CFIT, the post-test to follow-up interval was 240 days. The overall mean size of the long-term effect for Raven was -0.03 (- $0.14-$ 0.08 ; for $95 \%$ Confidence Interval, $p<.05)$. The sample consisted of 261 individuals in the experimental group $($ mean $=32.62 ; S D=7.29)$ and 211 in the control group $($ mean $=26.37 ; S D=$ 7.40). The heterogeneity of the group was moderate, with $\mathrm{Q}=17.22(p<.05)$ and $\mathrm{I}^{2}=59.36 \%$. For CFIT, the general mean size of the long-term effect was practically zero $(0.0001)$, with moderate heterogeneity among the studies, as $\mathrm{Q}=2.87$ $(p<.05)$ and $\mathrm{I}^{2}=30.22 \%$ ( $\mathrm{n}$ of the experimental and control groups, each $=58$, mean $=19.33$; $S D=1.15)$. It is important to note that the three studies using CFIT were published by the same group of principal investigators (Borella et al., 2014; Borella et al., 2013), which could indicate the presence of the same type of methodological bias. Therefore, for the results to be generalized, it would be necessary to expand the sample, with studies performed by independent research groups that used CFIT.

\section{Discussion}

This review aimed to perform a critical analysis of the available literature data to shed light on the controversy over the efficacy and transfer of gains from working memory training programs to fluid intelligence. In addition, it fo- cused on the identification of possible moderators of the transfer, to better understand which methodological variants could be contributing more effectively to the gains.

Regarding the main question of the present study, as related to the gains of WM training programs for a skill not directly trained by the program (in this case, those underlying the construct of fluid intelligence), it can be said that the results suggest that there is insufficient evidence that WM training produces immediate and widespread gains in fluid intelligence measures considered here. Although the mean effect sizes pointed to effects in favor of the experimental group, they were of small magnitude ( 0.09 for Raven and 0.24 for CFIT and BOMAT). It is important to consider that it was not possible to identify publication bias for the studies that used CFIT and BOMAT as measures of Gf, since the number of studies for these two measures was less than 10. Thus, it is not possible to know whether the mean effect size found would be maintained in the absence of bias, given that if the number of studies using these measures was higher, it would also increase the number of studies with null or negative effects, and, therefore, the mean effect size could be lower than that found in the present study. Therefore, considering that: (a) the studies using Raven were more numerous and had no publication bias; (b) the referred instrument is one of the most used instruments in studies that propose to measure $\mathrm{G} f$ and (c) this instrument has a high factorial load in the general factor of intelligence, it is possible to infer that the average results found in Raven reflect the effect size most likely in $G f$.

The results of studies that included a follow-up indicate that long-term gains ( 9 months maximum) tend to be null or zero. This means that even if there is a small increase in the skill directly trained by the program or indirect effects of theses on other associated cognitive abilities, these effects are not maintained over time. One of the main difficulties of cognitive training programs since its advent in the 1960s and 1970s, lies in what is known as fade-out effects (Hernstein \& Murray, 1994), that is, the waning of benefits obtained with participation 
in intervention programs, as soon as these programs are completed. It is possible to argue that, based on general principle of brain plasticity, the induction of it requires sufficient repetition. Although there is no consensus indicating the meaning of sufficient - especially for complex cognitive processes, such as WM or intelligence (Kleim \& Jones, 2008) - for plasticity to occur in brain systems with gains in some function or process, not only the acquisition, but the continuous use of that system over time is needed. The continuous use would be the cause for the newly acquired behaviour or ability not to be lost in the absence of training (Monfils, Plautz, $\&$ Kleim, 2005). If an individual who undergoes a cognitive training program does not have or does not create adequate opportunities to use the new acquired cognitive repertoire, his system would return to the initial state (before training). In this sense, this has been defended as the importance of considering the ecological validity of the tasks used in the training programs and the teaching of cognitive and metacognitive strategies in a direct and conscious way (Bahar-Fuchs, Clare, \& Woods, 2013; Green \& Bavelier, 2008: McDaniel \& Bugg, 2012). The trained strategies and tasks used in the laboratory have, in many cases, little resemblance to the demands encountered by the subjects in their daily lives. It could be more relevant and efficient to train specific strategies (subvocal rehersal, organization, establishment of relationships, among others) that could be applied to the solution of diverse problems and that could be generalized to other situations and activities. McDaniel and Bugg (2012) further emphasize that training programs that have positive results in terms of plasticity brain systems, are those whose tasks used for training have direct repercussion on the lives of trained individuals. Healy, Wohldmann, Parker, and Bourne (2005) believe that one solution would be to opt for what they call distributed practice in training programs. Distributed practice consists of delivering activities that can accelerate cognitive development or promote intellectual changes over a longer period. It would be the same as creating a WM training program, for example, that could be applied throughout the school year, once a week, at home and at school. In the specific case of the Brazilian context and the organization of our current formal education system, it is understood that it is practically impossible to establish a training program based on a distributed practice without public power support or more effective education policies.

From an optimistic point of view, one could say that, although small, there would be an effect of transferring training from WM to fluid intelligence, which could ultimately and at long term lead to a positive impact on social and educational indicators (Chein \& Morrison, 2010; Buschkuehl \& Jaeggi, 2010). However, this small effect could be subject to several other interpretations, including failures in evaluation methods, not necessarily indicating real gains in this capacity. This hypothesis is defended by Hayes et al. (2015), who affirms that gains in intelligence test scores can occur without increase in processing speed and capacity, and may indicate the development of strategies, including visual analysis. According to these authors, there are two ways to verify whether the WM gains actually transfer to $\mathrm{G} f$. One of them is the inclusion of multiple measures of $\mathrm{G} f$, which would allow the extraction of a latent factor. The second, which has been used by those authors is to analyze the ocular fixation pattern to infer if the refinement of strategies could be responsible for the test-retest gains observed in Gf. Hayes et al. (2015) states that this small effect observed in WM training to $\mathrm{G} f$ could be explained by the development of better elaborated and more refined visual strategies. It would also be possible to hypothesize that the development of more refined strategies of visual analysis could act as a mediator of observed gains. Considering the idea of mediation of gains it is important to highlight the role of the attention resources. Attention can be understood as a set of processes that favor the selection and distribution of processing resources of the cognitive system, and is therefore ultimately important for the efficiency of the superior cognitive functioning (Schweizer $\&$ Moosbrugger, 2004). Different types of attention, but especially the executive attention, have been associated with both working mem- 
ory and intelligence (Schweizer \& Koch, 2002; Schweizer, Moosbrugger, \& Goldhamme, 2005; Schweizer, Zimmermann, \& Koch, 2001). Both attention and WM, predict performance on intelligence tests, although it is unclear how this relationship happens, and there may be unrelated contributions or interdependence. Schweizer and Moosbrugger (2004) tested, through confirmatory factorial analysis, different models of the relationship between WM, attention and intelligence (measured by Raven Progressive Matrices - Advanced Scale) in a sample of university students and concluded that attention contributes to the performance on the intelligence test, separately and through working memory. This implies that the ability to maintain high level of attention and coordinate different cognitive resources is especially important when complex cognitive tasks need to be finalized. Extending these results to training programs is feasible to infer that attention could be and act as a mediator of cognitive gains and that complementing that with attentional training (other types of attention) to working memory could potentiate future gains. Green and Bavelier (2008) point to the promising results that are found in formal and informal training that use multicomponent intervention models that consider attention as an essential component of intervention programs. The present study does not allow us to affirm anything about the role of attention as a likely mediator of gains in WM training programs in intelligence, nor does it allow us to verify the unique and differential contribution of training programs focusing exclusively on attentional processes and their impact on fluid intelligence measures. In this sense, until the mechanisms involved in this transference are better described, it cannot be said with certainty that the effects of WM training are transferred to fluid intelligence, at least not directly, and may even be mediated by other cognitive functions or strategies used for problem solving or attention.

Moderator analysis was performed only for Raven and an important pattern emerged: significant gains for children and adolescents in comparison with adults, for longer duration training and for visuospatial WM tasks. Brain plasticity seems to be an important factor in determining gains in untrained skill and abilities, especially for children and adolescents. Plasticity is related to neurochemical and structural changes in the nervous system that can be induced by training of experiences in cognitively enriched environments. Although the capacity for these changes is present in all stages of life, during childhood the responses to environmental stimulation are faster and seem to occur on a larger and greater magnitude than in later stages of development (Astle et al., 2015; Rosenzweig \& Bennett, 1996). In addition to plasticity issues, some authors have suggested that short term (even intensive) training would not be sufficient to include brain plasticity in a skill traditionally refractory to change, such as fluid intelligence (Astle et al., 2015; Chein \& Morrison, 2010; Melby-Lervåg \& Hulme, 2013, 2015). This seems to corroborate the results found here that longer duration training would be more effective. A more intense practice would therefore be necessary not only to enable the desired change, but also to maintain that change. Rosenzweig and Bennett (1996) point out that although environments and training may not reverse a whole series of deficits present in the individual, the stimulation needs to be constant and the programs should be maintained for longer periods. This would enable the constant challenge of the cognitive system and would consolidate the gains obtained for the longest duration (von Bastian \& Eschen, 2016). Although it is not possible to know, so far, what would be the ideal dose of training, short-term intervention programs may not lead to gains in untrained skills. Thus, the results found seem to indicate that the gains would be of specific modality. Only visuospatial working memory tasks produced (even if small) effects on Raven. Although Raven test does no demand/require visuospatial processing skills in all its items, some items of the matrix series saturate visuospatial components, which are also present in the visuospatial WM tasks included in the training programs analyzed here (Gignac, 2015; Hayes et al., 2015). However, to verify whether the gains are in fact of specific modalities or whether they would be of general domination (for example in 
the central executive), it would be important to include as a measure of efficacy, a battery of fluid intelligence tests. This battery should include most, if not all, of the operations characteristic of the fluid intelligence construct, such as recognition and concept formation, problem solving, inference and transformation of information in verbal and nonverbal modalities.

Despite these results and proposed discussions, it is known that the present review has some limitations. There were no searches in dissertation banks and in annals of conferences, and no contact was made with researchers to obtain the complete text, when it was not available in the accessed databases. Therefore, the potentially missing data could reveal a bias in our analysis of publications. In addition, due to the small number of available studies in the literature and retained for analyses, it was not possible to investigate the potential differential effects of $\mathrm{G} f$ transfer from WM training to distinct clinical group and, also, for children and adolescents at different ages and therefore different stages of cognitive and neuronal development. In the latter case, it was not possible to test the hypothesis that the observed effects should be greater for children in the earlier stages of development. The presented limitations do not compromise the value of the results found, but point to the need of future reviews that consider and overcome the limitations listed here.

\section{Conclusions}

Overall, the present review did not find robust evidence of transfer of gains to fluid intelligence from working memory trainings. The obtained results point to derisory gains, which were limited to children with typical development. In addition, the methodological quality of the studies investigating the subject and included raise some doubts. It was not possible to analyze differences in the average effect between clinical and nonclinical samples and for different types of training practice (distributed and concentrated). Only three studies included clinical groups and only four worked with distributed practice (intense and continuous). It is often stated that
WM training programs could be beneficial to clinical populations (Cortese et al., 2015). It is not possible to know whether future studies will find consistent transfer effects to fluid intelligence measures, but until the transfer of gains to measure of cognitive and school performance (verbal and arithmetic skill) is consistently studied, clinical and widespread use of such programs should be reduced and performed more cautiously, if the intention is to achieve gains in intelligence (Redick et al., 2015).

\section{References}

Ackerman, P. L., Beier, M. E., \& Boyle, M. O. (2005). Working memory and intelligence: The same or different constructs? Psychological Bulletin, 131(1), 30. doi:10.1037/0033-2909.131.1.30

Alloway, T. P., Bibile, V., \& Lau, G. (2013). Computerized working memory training: Can it lead to gains in cognitive skills in students? Computers in Human Behavior, 29(3), 632-638. doi:10.1016/j.chb.2012.10.023

Astle, D. E., Barnes, J. J., Baker, K., Colclough, G. L., \& Woolrich, M. W. (2015). Cognitive training enhances intrinsic brain connectivity in childhood. The Journal of Neuroscience, 35(16), 6277-6283. doi:10.1523/JNEUROSCI.4517-14.2015

Au, J., Sheehan, E., Tsai, N., Duncan, G. J., Buschkuehl, M., \& Jaeggi, S. M. (2015). Improving fluid intelligence with training on working memory: A meta-analysis. Psychonomic Bulletin \& Review, 22(2), 366-377. doi:10.3758/s13423014-0699-x

Baddeley, A. (2003). Working memory: Looking back and looking forward. Nature Reviews Neuroscience, 4(10), 829-839. doi:10.1038/nrn1201

Bahar-Fuchs, A., Clare, L., \& Woods, B. (2013). Cognitive training and cognitive rehabilitation for persons with mild to moderate dementia of the Alzheimer's or vascular type: A review. $\mathrm{Al}$ zheimer's Research \& Therapy, 5(4), 1-14. Retrieved from http://alzres.com/content/5/4/35

Barnet, S. M., \& Ceci, S. J. (2002). When and where do we apply what we learn?: A taxonomy for far transfer. Psychological Bulletin, 128(4), 612. doi:10.1037/0033-2909.128.4.612

*Borella, E., Carretti, B., Cantarella, A., Riboldi, F., Zavagnin, M., \& De Beni, R. (2014). Benefits of 
training visuospatial working memory in youngold and old-old. Developmental Psychology, 50(3), 714-727. doi:10.1037/a0034293

*Borella, E., Carretti, B., Riboldi, F., \& De Beni, R. (2010). Working memory training in older adults: Evidence of transfer and maintenance effects. Psychology and Aging, 25(4), 767-778. doi:10.1037/a0020683

*Borella, E., Carretti, B., Zanoni, G., Zavagnin, M., \& De Beni, R. (2013). Working memory training in old age: An examination of transfer and maintenance effects. Archives of Clinical Neuropsychology: The Official Journal of the $\mathrm{Na}$ tional Academy of Neuropsychologists, 28(4), 331-347. doi:10.1093/arclin/act020

Borenstein, M., Hedges, L. V, Higgins, J. P. T., \& Rothstein, H. R. (2009). Subgroup analyses. In M. Borenstein, L. V Hedges, J. P. T. Higgins, \& H. R. Rothstein (Eds.), Introduction to MetaAnalysis. Chichester, UK: John Wiley \& Sons.

*Brehmer, Y., Westerberg, H., \& Bäckman, L. (2012, March). Working-memory training in younger and older adults: Training gains, transfer, and maintenance. Frontiers in Human Neuroscience, 6, 63. doi:10.3389/fnhum.2012.00063

Buschkuehl, M., \& Jaeggi, S. M. (2010). Improving intelligence: A literature review. Swiss Medical Weekly, 140(19-20), 266-272. doi:10.1.1.613.2047

Burt, C. (1962). Francis Galton and his contributions to psychology. British Journal of Statistical Psychology, 15(1), 1-49. doi:10.1111/j.2044-8317.1962.tb00081.x

Carpenter, P. A., Just, M. A., \& Shell, P. (1990). What one intelligence test measures: A theoretical account of the processing in the Raven Progressive Matrices Test. Psychological review, 97(3), 404. doi:10.1037/0033-295X.97.3.404

*Carretti, B., Borella, E., Fostinelli, S., \& Zavagnin, M. (2013). Benefits of training working memory in amnestic mild cognitive impairment: Specific and transfer effects. International Psychogeriatrics / IPA, 25(4), 617-626. doi:10.1017/S1041610212002177

*Chein, J. M., \& Morrison, A. B. (2010). Expanding the mind's workspace: Training and transfer effects with a complex working memory span task. Psychonomic Bulletin \& Review, 17(2), 193-199. doi:10.3758/PBR.17.2.193
*Chooi, W.-T., \& Thompson, L. A. (2012). Working memory training does not improve intelligence in healthy young adults. Intelligence, 40(6), 531-542. doi:10.1016/j.intell.2012.07.004

Colom, R., Jung, R. E., \& Haier, R. J. (2007). General intelligence and memory span: Evidence for a common neuroanatomic framework. Cognitive Neuropsychology, 24(8), 867-878. doi:10.1080/02643290701781557

*Colom, R., Román, F. J., Abad, F. J., Shih, P. C., Privado, J., Froufe, M., ...Jaeggi, S. M. (2013). Adaptive n-back training does not improve fluid intelligence at the construct level: Gains on individual tests suggest that training may enhance visuospatial processing. Intelligence, 41(5), 712-727. doi:10.1016/j.intell.2013.09.002

Cortese, S., Ferrin, M., Brandeis, D., Buitelaar, J., Daley, D., Dittmann, R. W., ...Zuddas, A. (2015). Cognitive training for attention-deficit/ hyperactivity disorder: Meta-analysis of clinical and neuropsychological outcomes from randomized controlled trials. Journal of the American Academy of Child \& Adolescent Psychiatry, 54(3), 164-174. doi:10.1016/j.jaac.2014.12.010

*Dahlin, K. I. E. (2010). Effects of working memory training on reading in children with special needs. Reading and Writing, 24(4), 479-491. doi:10.1007/s11145-010-9238-y

Deary, I. J., Penke, L., \& Johnson, W. (2010). The neuroscience of human intelligence differences. Nature Reviews Neuroscience, 11(3), 201-211. doi:10.1038/nrn2793

Flynn, J. R. (1987). Massive IQ gains in 14 nations: What IQ tests really measure. Psychological Bulletin, 101(2), 171-191. doi:10.1037/00332909.101.2.171

Flynn, J. R. (2006). Thethering the elephant: Capital cases, IQ, and the Flynn effect. Psychology, Public Policy, and Law, 12(2), 170-189. doi:10.1037/1076-8971.12.2.170

Gignac, G. E. (2015). Raven's is not a pure measure of general intelligence: Implications for $\mathrm{g}$ factor theory and the brief measurement of g. Intelligence, 52, 71-79. doi:10.1016/j.intell.2015.07.006

Gray, J. R., \& Thompson, P. M. (2004). Neurobiology of intelligence: Science and ethics. Nature Reviews Neuroscience, 5(6), 471-482. doi:10.1038/nrn1405 
Green, C. S., \& Bavelier, D. (2008). Exercising your brain: A review of human brain plasticity and training-induced learning. Psychology and Aging, 23(4), 692-701. doi:10.1037/a0014345

*Harrison, T. L., Shipstead, Z., Hicks, K. L., Hambrick, D. Z., Redick, T. S., \& Engle, R. W. (2013). Working memory training may increase working memory capacity but not fluid intelligence. Psychological Science, 24(12), 2409 2019. doi:10.1177/0956797613492984

Hayes, T. R., Petrov, A. A., \& Sederberg, P. B. (2015). Do we really become smarter when our fluid-intelligence test scores improve?. Intelligence, 48, 1-14. doi:10.1016/j.intell.2014.10.005

Healy, A. F., Wohldmann, E. L., Parker, J. T., \& Bourne, L. E. (2005). Skill training, retention, and transfer: The effects of a concurrent secondary task. Memory \& Cognition, 33, 1457-1471. doi:10.3758/BF03193378

Hedges, L., \& Olkin, I. (1985). Statistical models for meta-analysis. New York: Academic

*Heinzel, S., Schulte, S., Onken, J., Duong, Q.-L., Riemer, T. G., Heinz, A., ... Rapp, M. A. (2014). Working memory training improvements and gains in non-trained cognitive tasks in young and older adults. Neuropsychology, Development, and Cognition. Section B, Aging, Neuropsychology and Cognition, 21(2), 146-173. doi: $10.1080 / 13825585.2013 .790338$

Higgins, J. P. T., Thompson, S. G., Deeks, J. J., \& Altman, D. G. (2003). Measuring inconsistency in meta-analyses. BMJ: British Medical Journal, 327(7414), 557-560. doi:10.1136/ bmj.327.7414.557

Ilkowska, M., \& Engle, R. W. (Eds.). (2010) Working memory capacity and self-regulation, in handbook of personality and selfregulation. Oxford, UK: Wiley-Blackwell. doi:10.1002/9781444318111.ch12

Jaeggi, S. M., Buschkuehl, M., Jonides, J., \& Perrig, W. J. (2008). Improving fluid intelligence with training on working memory. Proceedings of the National Academy of Sciences, 105(19), 6829. 6833. doi:10.1073/pnas.0801268105

*Jaeggi, S. M., Buschkuehl, M., Jonides, J., \& Shah, P. (2011). Short- and long-term benefits of cognitive training. Proceedings of the National Academy of Sciences of the United States of America, 108(25), 10081-10086. doi:10.1073/ pnas. 1103228108
*Jaeggi, S. M., Buschkuehl, M., Shah, P., \& Jonides, J. (2014). The role of individual differences in cognitive training and transfer. Memory \& Cognition, 42(3), 464-480. doi:10.3758/s13421013-0364-z

*Jaeggi, S. M., Studer-Luethi, B., Buschkuehl, M., Su, Y.-F., Jonides, J., \& Perrig, W. J. (2010). The relationship between n-back performance and matrix reasoning - Implications for training and transfer. Intelligence, 38(6), 625-635. doi:10.1016/j.intell.2010.09.001

*Jaušovec, N., \& Jaušovec, K. (2012). Working memory training: Improving intelligence--Changing brain activity. Brain and Cognition, 79(2), 96106. doi:10.1016/j.bandc.2012.02.007

Jensen, A.R. (1981). Raising the IQ: The Ramey and Haskins Study. Intelligence, 5, 29-40.

Jensen, A.R. (1998). The g factor. London: Praeger.

Jung, R. E., \& Haier, R. J. (2007). The Parieto-Frontal Integration Theory (P-FIT) of intelligence: Converging neuroimaging evidence. Behavioral and Brain Sciences, 30(02), 135-154. doi:10.1017/ S0140525X07001185

Kane, M. J., \& Engle, R. W. (2002). The role of prefrontal cortex in working-memory capacity, executive attention, and general fluid intelligence: An individual-differences perspective. Psychonomic Bulletin \& Review, 9(4), 637-671. doi:10.3758/BF03196323

Kleim, J. A., \& Jones, T. A. (2008). Principles of experience-dependent neural plasticity: implications for rehabilitation after brain damage. Journal of Speech, Language, and Hearing Research, 51, 225-239. doi:1092-4388/08/5101-S225

Klingberg, T. (2010). Training and plasticity of working memory. Trends in Cognitive Sciences, 14(7), 317-324. doi:10.1016/j.tics.2010.05.002

*Klingberg, T., Fernell, E., Olesen, P. J., Johnson, M., Gustafsson, P. E. R., Om, K. D., ...Westerberg, H. (2005). Computerized Training of Working Memory in Children with ADHD A randomized controlled trial. Journal of the American Academy of Child and Adolescent Psychiatry, 44(2), 177-186. doi:10.1097/00004583200502000-00010

*Klingberg, T., Forssberg, H., \& Westerberg, H. (2002). Training of working memory in children with ADHD. Journal of Clinical and Experimental Neuropsychology, 24(6), 781-791. doi:10.1076/jcen.24.6.781.8395 
*Kuwajima, M., \& Sawaguchi, T. (2010). Similar prefrontal cortical activities between general fluid intelligence and visuospatial working memory tasks in preschool children as revealed by optical topography. Experimental Brain Research, 206(4), 381-397. doi:10.1007/ s00221-010-2415-z

Kyllonen, P. C., \& Christal, R. E. (1990). Reasoning ability is (little more than) working-memory capacity?!. Intelligence, 14(4), 389-433. doi:10.1016/S0160-2896(05)80012-1

Li, Y., Liu, Y., Li, J., Qin, W., Li, K., Yu, C., \& Jiang, T. (2009). Brain anatomical network and intelligence. PLoS Comput Biol, 5(5), e1000395. doi:10.1371/journal.pcbi.1000395

Li, T., \& Shotton, K. (2013). Conventional occlusion versus pharmacologic penalization for amblyopia. NIH Public Access, (4). doi:1002/14651858. CD006460.pub2.Conventional

Hernstein, R. J., \& Murray, C. (1994). The Bell Curve: Intelligence and Class Structure in American Life. New York: Free Press.

*Mansur-Alves, M., Flores-Mendoza, C., \& TierraCriollo, C. J. (2013). Evidências preliminares da efetividade do treinamento cognitivo para melhorar a inteligência de crianças escolares. Psicologia: Reflexão e Crítica, (1981), 423-434. doi:10.1590/S0102-79722013000300001

McDaniel, M. A., \& Bugg, J. M. (2012). Memory training interventions: What has been forgotten? Journal of Applied Research in Memory and Cognition, 1, 45-50. Retrieved from http:// dx.doi.org/10.1016/j.jarmac.2011.11.002

McGrew, K. S. (2009). CHC theory and the human cognitive abilities project: Standing on the shoulders of the giants of psychometric intelligence research. Intelligence, 37(1), 1-10. doi:10.1016/j.intell.2008.08.004

Melby-Lervåg, M., \& Hulme, C. (2013). Is working memory training effective? A meta-analytic review. Developmental Psychology, 49(2), 270. doi:10.1037/a0028228

Melby-Lervåg, M., \& Hulme, C. (2015). There is no convincing evidence that working memory training is effective: A reply to Au et al. (2014) and Karbach and Verhaeghen (2014). Psychonomic Bulletin and Review, 23(1), 324-330. doi:10.3758/s13423-015-0862-z

Miller, E. K., \& Cohen, J. D. (2001). An integrative theory of pre-frontal cortex function. Annual Re- view of Neuroscience, 24, 167-202. doi:10.1146/ annurev.neuro.24.1.167

Monfils, M. H., Plautz, E. J., \& Kleim, J. A. (2005). In search of the motor engram: Motor map plasticity as a mechanism for encoding motor experience. Neuroscientist, 11, 471-483. doi: $10.1177 / 1073858405278015$

Neisser, U., Boodoo, G., Bouchard, T. J., Jr., Boykin, A., Brody, N., Ceci, S. J., ...Urbina, S. (1996). Intelligence: Knowns and unknowns. American Psychologist, 51(2), 77-101. doi:10.1037/0003066X.51.2.77

Neyeloff, J. L., Fuchs, S. C., \& Moreira, L. B. (2012). Meta-analyses and Forest plots using a Microsoft excel spreadsheet: Step-by-step guide focusing on descriptive data analysis. BMC Research Notes, 5(Mix), 52. doi:10.1186/1756-0500-5-52

Nisbett, R. E., Aronson, J., Blair, C., Dickens, W., Flynn, J., Halpern, D. F., \& Turkheimer, E. (2012). Intelligence: New findings and theoretical developments. American Psychologist, 67(2), 130-159. doi:10.1037/a0026699

Oberauer, K., Suß, H.-M., Schulze, R., Wilhelm, O., \& Wittmann, W. W. (2000). Working memory capacity facets of a cognitive ability construct. Personality and Individual Differences, 29, 1017-1045. doi:10.1016/S0191-8869(99)002512

*Oelhafen, S., Nikolaidis, A., Padovani, T., Blaser, D., Koenig, T., \& Perrig, W. J. (2013). Increased parietal activity after training of interference control. Neuropsychologia, 51(13), 2781-2790. doi:10.1016/j.neuropsychologia.2013.08.012

Orzechowski, J. (2010). Working memory capacity and individual differences in higher-level cognition. In A. Gruszka., G. Matthews., \& B. Szymura (Eds.), Handbook of Individual differences in cognition: Attention, memory, and executive control (pp. 353-368). London: Springer.

Pereira, M. G., \& Galvão, T. F. (2014). Heterogeneidade e viés de publicação em revisões sistemáticas. Epidemiologia e Serviços de Saúde, 23(4), 775-778. doi:10.5123/S167949742014000400021

*Pugin, F., Metz, A. J., Stauffer, M., Wolf, M., Jenni, O. G., \& Huber, R. (2015). Working memory training shows immediate and long-term effects on cognitive performance in children and adolescents. F1000Research, 1-10. doi:10.12688/ f1000research.3929 
*Redick, T. S., Shipstead, Z., Harrison, T. L., Hicks, K. L., Fried, D. E., Hambrick, D. Z., ...Engle, R. W. (2013). No evidence of intelligence improvement after working memory training: A randomized, placebo-controlled study. Journal of Experimental Psychology. General, 142(2), 359-379. doi:10.1037/a0029082

Redick, T. S., Shipstead, Z., Wiemers, E. A., Melby-Lervåg, M., \& Hulme, C. (2015). What's working in working memory training? An educational perspective. Educational Psychology Review, 27(4), 617-633. doi:10.1007/s10648015-9314-6

*Richmond, L. L., Morrison, A. B., Chein, J. M., \& Olson, I. R. (2011). Working memory training and transfer in older adults. Psychology and Aging, 26(4), 813-822. doi:10.1037/a0023631

Rosenzweig, M. R., \& Bennett, E. L. (1996). Psychobiology of plasticity: Effects of training and experience on brain and behavior. Behavioural Brain Research, 78(1), 57-65. doi:10.1016/01664328(95)00216-2

*Rudebeck, S. R., Bor, D., Ormond, A., O’Reilly, J. X., \& Lee, A. C. H. (2012). A potential spatial working memory training task to improve both episodic memory and fluid intelligence. PloS One, 7(11), e50431. doi:10.1371/journal. pone. 0050431

Rushton, J. P. (1990). Sir Francis Galton, epigenetic rules, genetic similarity theory, and human life-history analysis. Journal of Personality, 58(1), 117-140. doi:10.1111/j.1467-6494.1990. tb00910.x

*Salminen, T., Strobach, T., \& Schubert, T. (2012, June). On the impacts of working memory training on executive functioning. Frontiers in Human Neuroscience, 6, 166. doi:10.3389/ fnhum.2012.00166

Schmiedek, F., Lövdén, M., \& Lindenberger, U. (2010). Hundred days of cognitive training enhance broad cognitive abilities in adulthood: Findings from the COGITO study. Frontiers in Aging Neuroscience, 2, 27. doi:10.3389/ fnagi.2010.00027

Schweizer, K. \& Koch, W. (2002). A revision of Cattell's Investment Theory Cognitive properties influencing learning. Learning and Individual Difference, 13, 57-82. doi:10.1016/S10416080(02)00062-6
Schweizer, K., \& Moosbrugger, H. (2004). Attention and working memory as predictors of intelligence. Intelligence, 32(4), 329-347. doi:10.1016/j.intell.2004.06.006

Schweizer, K., Moosbrugger, H., \& Goldhammer, F. (2005). The structure of the relationship between attention and intelligence. Intelligence, 33(6), 589-611. doi:10.1016/j.intell.2005.07.001

Schweizer, K., Zimmermann, P., \& Koch, W. (2001). Sustained attention, intelligence and the crucial role of perceptual processes. Learning and Individual Differences, 12, 271-286. doi:10.1016/ S1041-6080(01)00040-1

Shipstead, Z., Redick, T. S., \& Engle, R. W. (2012). Is working memory training effective?. Psychological Bulletin, 138(4), 628. doi:10.1037/ a0027473

Sprenger, A. M., Atkins, S. M., Bolger, D. J., Harbison, J. I., Novick, J. M., Chrabaszcz, J. S., ... Bunting, M. F. (2013). Training working memory: Limits of transfer. Intelligence, 41(5), 638663. doi:10.1016/j.intell.2013.07.013

Stauffer, J. M., Ree, M. J., \& Caretta, T. R. (1996). Cognitive-components tests are not much more than g: An extension of Kyllonen's analysis. Journal of General Psychology, 123, 193-205. doi:10.1080/00221309.1996.9921272

*Stephenson, C. L., \& Halpern, D. F. (2013). Improved matrix reasoning is limited to training on tasks with a visuospatial component. Intelligence, 41(5), 341-357. doi:10.1016/j.intell.2013.05.006

Strenze, T. (2007). Intelligence and socioeconomic success: A meta-analytic review of longitudinal research. Intelligence, 35(5), 401-426. doi:10.1016/j.intell.2006.09.004

*Thompson, T. W., Waskom, M. L., Garel, K.-L. A., Cardenas-Iniguez, C., Reynolds, G. O., Winter, R., ...Gabrieli, J. D. E. (2013). Failure of working memory training to enhance cognition or intelligence. PloS One, 8(5), e63614. doi:10.1371/ journal.pone.0063614

*Van der Molen, M. J., Van Luit, J. E. H., Van der Molen, M. W., Klugkist, I., \& Jongmans, M. J. (2010). Effectiveness of a computerised working memory training in adolescents with mild to borderline intellectual disabilities. Journal of Intellectual Disability Research : JIDR, 54(5), 433447. doi:10.1111/j.1365-2788.2010.01285.x 
Von Bastian, C. C., \& Eschen, A. (2016). Does working memory training have to be adaptive?. Psychological research, 80(2), 181-194. doi:10.1007/s00426-015-0655-z

*Von Bastian, C. C., Langer, N., Jäncke, L., \& Oberauer, K. (2013). Effects of working memory training in young and old adults. Memory \& Cognition, 41(4), 611-624. doi:10.3758/s13421012-0280-7

Wang, Z., Zhou, R., \& Shah, P. (2014). Spaced cognitive training promotes training transfer. Frontiers in Human Neuroscience, 8, 1-8. doi:10.3389/fnhum.2014.00217

Woolgar, A., Parr, A., Cusack, R., Thompson, R., Nimmo-Smith, I., Torralva, T., ...Duncan, J. (2010). Fluid intelligence loss linked to restricted regions of damage within frontal and parietal cortex. Proceedings of the National Academy of Sciences, 107(33), 14899-14902. doi:10.1073/ pnas. 1007928107
*Xin, Z., Lai, Z.-R., Li, F., \& Maes, J. H. R. (2014). Near- and far-transfer effects of working memory updating training in elderly adults. $A p$ plied Cognitive Psychology, 28(3), 403-408. doi:10.1002/acp.3011

*Zinke, K., Zeintl, M., Rose, N. S., Putzmann, J., Pydde, A., \& Kliegel, M. (2014). Working memory training and transfer in older adults: Effects of age, baseline performance, and training gains. Developmental Psychology, 50(1), 304-315. doi:10.1037/a0032982
Recebida: $25 / 07 / 2016$

$1^{a}$ revisão: $1 \% 11 / 2016$

Aceite final: 28/11/2016 


\section{Appendix A}

Table 1A

Characterization of the Selected Studies

\begin{tabular}{|c|c|c|c|c|c|c|c|c|}
\hline \multirow{2}{*}{ Reference } & \multicolumn{2}{|c|}{ Mean age (SD) } & \multirow[t]{2}{*}{$\begin{array}{c}n \\
\mathbf{E G}\end{array}$} & \multirow[t]{2}{*}{$\stackrel{n}{\mathbf{C G}}$} & \multirow[t]{2}{*}{$\begin{array}{l}\text { Incen- } \\
\text { tive }\end{array}$} & \multirow[t]{2}{*}{$\begin{array}{l}\text { Days of } \\
\text { training }\end{array}$} & \multirow[t]{2}{*}{$\begin{array}{l}\text { Type of } \\
\text { training }\end{array}$} & \multirow[t]{2}{*}{ G $\boldsymbol{f}$ task } \\
\hline & EG & CG & & & & & & \\
\hline (Klingberg et al., 2002) & $11(2)$ & $11.4(3)$ & 7 & 7 & NI & 21 & Combined & Raven \\
\hline (Klingberg et al., 2005) & $9.8(1.4)$ & $9.7(1.3)$ & 22 & 22 & NI & 35 & Combined & Raven \\
\hline (Dahlin, 2010) & NI & NI & 42 & 15 & NI & 35 & Combined & Raven \\
\hline $\begin{array}{l}\text { (Kuwajima \& Sawaguchi, } \\
\text { 2010) }\end{array}$ & NI & NI & 20 & 40 & NI & 56 & Visuospatial & CFIT \\
\hline $\begin{array}{l}\text { (Van der Molen, Van Luit, } \\
\text { Van der Molen, Klugkist, } \\
\text { \& Jongmans, 2010) }\end{array}$ & $15.3(0.69)$ & NI & 41 & 54 & $\mathrm{P}$ & 35 & Visuospatial & Raven \\
\hline (Chein \& Morrison, 2010) & $20.1(\mathrm{NI})$ & $20.6(\mathrm{NI})$ & 21 & 21 & $\mathrm{P}$ & 30 & Combined & Raven \\
\hline (Jaeggi et al., 2010) & $19(1.5)$ & $19(1)$ & 21 & 43 & $\mathrm{P}$ & 30 & Visuospatial & $\begin{array}{l}\text { BOMAT } \\
\text { Raven }\end{array}$ \\
\hline (Jaeggi et al., 2010) & $19.1(1.2)$ & $19(1)$ & 25 & 43 & $\mathrm{P}$ & 35 & Combined & $\begin{array}{l}\text { BOMAT } \\
\text { Raven }\end{array}$ \\
\hline (Borella et al., 2010) & $69(3.2)$ & $69.1(2.9)$ & 20 & 20 & NI & 14 & $\begin{array}{l}\text { Alphabeti- } \\
\text { cal-verbal }\end{array}$ & CFIT \\
\hline (Jaeggi et al., 2011) & $9.1(1.5)$ & $8.8(1.4)$ & 32 & 30 & NI & 30 & Visuospatial & Raven \\
\hline $\begin{array}{l}\text { (Richmond, Morrison, } \\
\text { Chein, \& Olson, 2011) }\end{array}$ & NI & NI & 21 & 19 & NI & 35 & Combined & Raven \\
\hline $\begin{array}{l}\text { (Salminen, Strobach, } \\
\text { \& Schubert, 2012) }\end{array}$ & $24.4(\mathrm{NI})$ & 24.5 (NI) & 20 & 18 & $\mathrm{P}$ & 21 & Combined & Raven \\
\hline $\begin{array}{l}\text { (Brehmer, Westerberg, \& } \\
\text { Bäckman, 2012) }\end{array}$ & $26.2(2.8)$ & $25.7(3.5)$ & 29 & 26 & $\mathrm{P}$ & 35 & Combined & Raven \\
\hline (Brehmer et al., 2012) & $63.9(3.4)$ & $63.6(3.1)$ & 26 & 19 & $\mathrm{P}$ & 42 & Combined & Raven \\
\hline (Chooi \& Thompson, 2012) & $20(\mathrm{NI})$ & NI & 9 & 15 & $\mathrm{P}$ & 21 & Combined & Raven \\
\hline (Chooi \& Thompson, 2012) & $20(\mathrm{NI})$ & NI & 13 & 11 & $\mathrm{P}$ & 35 & Combined & Raven \\
\hline (Jaušovec \& Jaušovec, 2012) & $20(\mathrm{NI})$ & 20 & 14 & 15 & $\mathrm{P}$ & 84 & Combined & Raven \\
\hline (Rudebeck et al., 2012) & $25.4(4.4)$ & $25.5(4.7)$ & 27 & 28 & NI & 30 & Visuospatial & BOMAT \\
\hline (Oelhafen et al., 2013) & NI & NI & 14 & 8 & $\mathrm{P}$ & 21 & Combined & BOMAT \\
\hline (Oelhafen et al., 2013) & NI & NI & 14 & 8 & $\mathrm{P}$ & 21 & Combined o & BOMAT \\
\hline (Von Bastian et al., 2013) & $23(4)$ & $23(4)$ & 34 & 32 & $\mathrm{P}$ & 30 & Combined & $\begin{array}{l}\text { Raven/ } \\
\text { BOMAT. }\end{array}$ \\
\hline (Von Bastian et al., 2013) & $68(4)$ & $69(3)$ & 27 & 30 & $\mathrm{P}$ & 30 & Combined & $\begin{array}{l}\text { Raven/ } \\
\text { BOMAT }\end{array}$ \\
\hline (Colom et al., 2013) & $18(.90)$ & $18.2(1.2)$ & 28 & 28 & NI & 84 & Combined & Raven \\
\hline (Harrison et al., 2013) & NI (NI) & NI & 21 & 17 & $\mathrm{P}$ & 30 & Combined & Raven \\
\hline (Harrison et al., 2013) & NI & NI & 17 & 17 & $\mathrm{P}$ & 35 & Combined & Raven \\
\hline (Redick et al., 2013) & $21.1(2.7)$ & $20.7(2.5)$ & 24 & 29 & NI & 30 & Combined & $\begin{array}{l}\text { Raven/ } \\
\text { CFIT }\end{array}$ \\
\hline
\end{tabular}




\begin{tabular}{|c|c|c|c|c|c|c|c|c|}
\hline \multirow{2}{*}{ Reference } & \multicolumn{2}{|c|}{ Mean age (SD) } & \multirow[t]{2}{*}{$\begin{array}{c}n \\
\text { EG }\end{array}$} & \multirow[t]{2}{*}{$\begin{array}{c}n \\
\mathbf{C G}\end{array}$} & \multirow[t]{2}{*}{$\begin{array}{l}\text { Incen- } \\
\text { tive }\end{array}$} & \multirow[t]{2}{*}{$\begin{array}{l}\text { Days of } \\
\text { training }\end{array}$} & \multirow[t]{2}{*}{$\begin{array}{l}\text { Type of } \\
\text { training }\end{array}$} & \multirow[t]{2}{*}{ G $\boldsymbol{f}$ task } \\
\hline & EG & CG & & & & & & \\
\hline (Sprenger et al., 2013) & NI & NI & 33 & 37 & $\mathrm{P}$ & 42 & Visuospatial & Raven \\
\hline $\begin{array}{l}\text { (Stephenson \& Halpern, } \\
\text { 2013) }\end{array}$ & NI & NI & 28 & 28 & $\mathrm{P}$ & 30 & Combined & $\begin{array}{l}\text { Raven/ } \\
\text { CFIT }\end{array}$ \\
\hline $\begin{array}{l}\text { (Stephenson \& Halpern, } \\
\text { 2013) }\end{array}$ & NI & NI & 29 & 28 & $\mathrm{P}$ & 35 & Visuospatial & $\begin{array}{l}\text { Raven/ } \\
\text { CFIT }\end{array}$ \\
\hline $\begin{array}{l}\text { (Stephenson \& Halpern, } \\
\text { 2013) }\end{array}$ & NI & NI & 25 & 28 & $\mathrm{P}$ & 42 & $\begin{array}{l}\text { Alphabetical- } \\
\text { verbal }\end{array}$ & $\begin{array}{l}\text { Raven/ } \\
\text { CFIT }\end{array}$ \\
\hline (Thompson et al., 2013) & $21.2(\mathrm{NI})$ & $21.3(\mathrm{NI})$ & 20 & 19 & $\mathrm{P}$ & 30 & Combined & Raven \\
\hline $\begin{array}{l}\text { (Mansur-Alves, Flores- } \\
\text { Mendoza, \& Tierra-Criollo, } \\
\text { 2013) }\end{array}$ & NI & NI & 8 & 8 & A & 84 & $\begin{array}{l}\text { Alphabetical- } \\
\text { verbal }\end{array}$ & Raven \\
\hline (Borella et al., 2013) & $79.2(3.49)$ & $79.1(2.95)$ & 18 & 18 & NI & 21 & $\begin{array}{l}\text { Alphabetical- } \\
\text { verbal }\end{array}$ & CFIT \\
\hline $\begin{array}{l}\text { (Carretti, Borella, Fostinelli, } \\
\text { \& Zavagnin, 2013) }\end{array}$ & $71.8(2.2)$ & $70.6(2.63)$ & 10 & 10 & NI & 21 & $\begin{array}{l}\text { Alphabetical- } \\
\text { verbal }\end{array}$ & CFIT \\
\hline (Heinzel et al., 2014) & $25.9(1.9)$ & $25.6(2.1)$ & 15 & 15 & $\mathrm{P}$ & 30 & $\begin{array}{l}\text { Alphabetical- } \\
\text { verbal }\end{array}$ & Raven \\
\hline (Heinzel et al., 2014) & $66(4.7)$ & $65.6(3.9)$ & 15 & 15 & $\mathrm{P}$ & 35 & $\begin{array}{l}\text { Alphabetical- } \\
\text { verbal }\end{array}$ & Raven \\
\hline (Borella et al., 2014) & $69.9(2.8)$ & $69.5(2.9)$ & 20 & 20 & NI & 14 & Visuospatial & Cattell \\
\hline (Borella et al., 2014) & $79.6(2.3)$ & $79.7(2.3)$ & 20 & 20 & NI & 14 & Visuospatial & Cattell \\
\hline (Xin, Lai, Li, \& Maes, 2014) & $70(5.8)$ & $69(7.0)$ & 15 & 14 & $\mathrm{P}$ & 21 & Combined & Raven \\
\hline (Zinke et al., 2014) & $75.7(8.4)$ & 77.7 (7.9) & 40 & 40 & A & 21 & Combined & Raven \\
\hline $\begin{array}{l}\text { (Jaeggi, Buschkuehl, Shah, \& } \\
\text { Jonides, 2014) }\end{array}$ & NI & NI & 25 & 27 & A & 30 & Combined & $\begin{array}{l}\text { Raven/ } \\
\text { BOMAT }\end{array}$ \\
\hline (Jaeggi et al., 2014) & NI & NI & 26 & 27 & A & 30 & $\begin{array}{l}\text { Alphabetical- } \\
\text { verbal }\end{array}$ & $\begin{array}{l}\text { Raven/ } \\
\text { BOMAT }\end{array}$ \\
\hline
\end{tabular}

Note. CG - Control Group; EG - Experimental Group; NI - Not Informed; P - present; A - absent. 
Appendix B

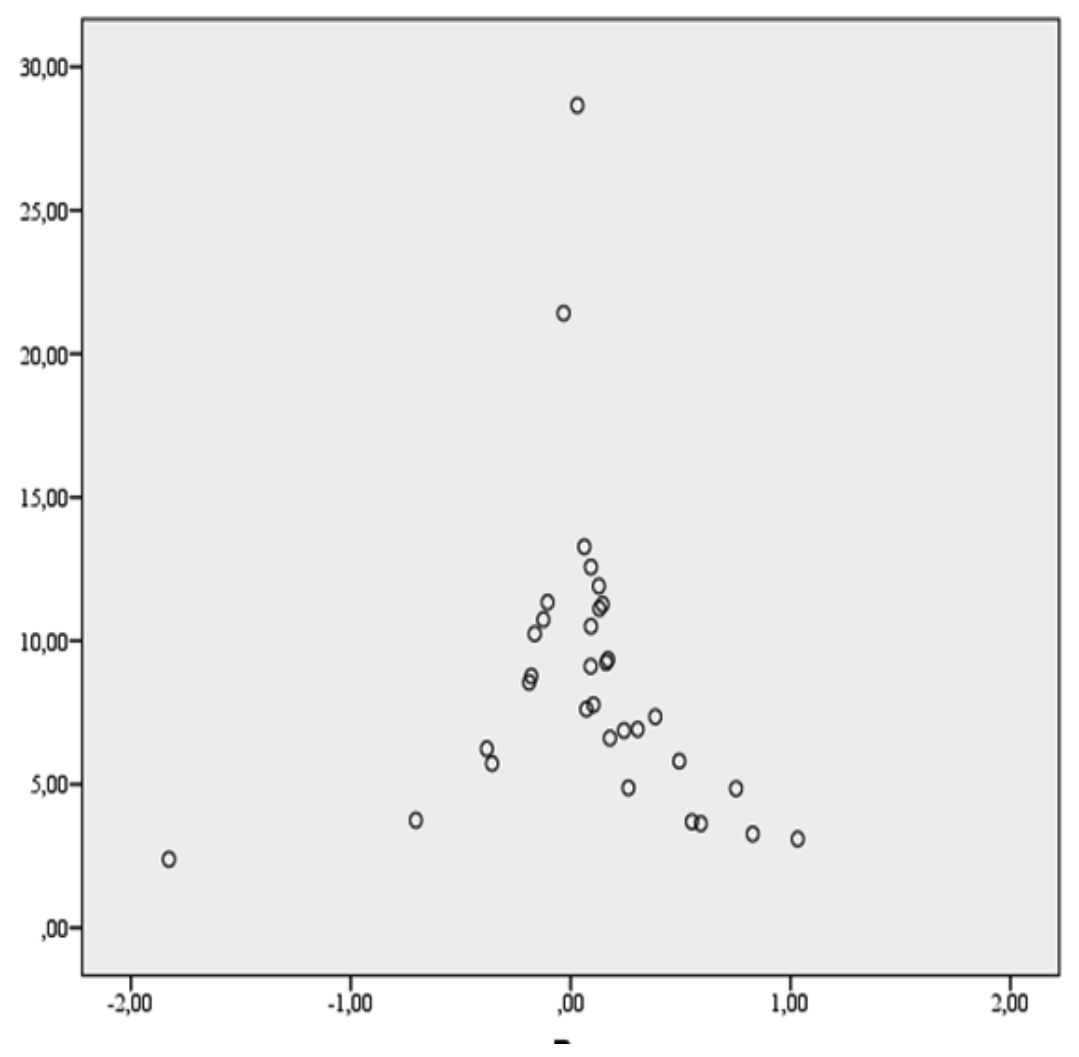

Figure 1B. Funnel plot for the Raven Test. 